Original Article

\title{
Productive potential of Tectona grandis in Midwest Brazil
}

\author{
Reginaldo Antonio Medeiros ${ }^{1 *}$, Haroldo Nogueira de Paiva ${ }^{2}$, Álvaro Augusto Vieira Soares ${ }^{3}$, Gustavo Eduardo \\ Marcatti $^{4}$, Fausto Hissahi Takizawa ${ }^{5}$, Carlos Alberto Ramos Domiciano ${ }^{1}$, Helio Garcia Leite ${ }^{2}$
}

${ }^{1}$ Federal Institute of Mato Grosso, Ramieres Avenue, Distrito Industrial, Cáceres - MT, 78200-000

${ }^{2}$ Federal University of Viçosa, Peter Henry Rolfs Avenue, University Campus, Viçosa - MG, 36570-900

${ }^{3}$ Federal University of Uberlândia, João Naves de Ávila Avenue, 2121, Santa Mônica, Uberlândia - MG, 38408-100

${ }^{4}$ Federal University of São João del-Rei, Frei Orlando Square, 170, Downtown, São João Del-Rei, MG, 36307-352.

${ }^{5}$ Teak Resources Company, M. Castelo Branco Avenue, 272, São Miguel,Cáceres, MT, 78200-000

*Author for correspondence: reginaldo.medeiros@ cas.ifmt.edu.br

Received: July 2019/ Accepted: October 2019 / Published: December 2019

\begin{abstract}
This study aimed to assess the productive potential of teak plantations in the state of Mato Grosso, Midwest Brazil. We modeled the mean annual increment at the age of 12 years (MAI12) as a function of climatic, edaphic and phy siographic variables using artificial neural networks (ANN). The ANNs were shown effective in modeling the mean annual increment, despite of some inconsistences found for areas for which part of the environmental information was not available. The greatest proportion of the land covered by our study $(62 \%)$ presented moderate productivity, ranging from $10.24 \mathrm{~m} 3$ ha1 year-1 to $28.76 \mathrm{~m} 3$ ha 1 year 1 MAI12. The highest (M AI12 $>28.76 \mathrm{~m} 3$ ha-1 year-1) and the lowest (MAI12 < $10.24 \mathrm{~m} 3$ ha 1 year 1) productivity areas accounted for $18 \%$ and $20 \%$ of the study area, respectively. Studies comprising a more comprehensive coverage of the teak production areas are encouraged in order to improve estimation accuracy.
\end{abstract}

Keywords: teak, neural networks, productive capacity.

\section{Introduction}

Brazil is a leading country in terms of productivity of tree plantations. Through intensive research and continuous improvement in silviculture (Gonçalves et al. 2004), pine and eucalypt plantations in Brazil present, respectively, average national productivities of $30.1 \mathrm{~m}^{3}$ ha 1 year 1 and $36.0 \mathrm{~m}^{3}$ ha 1 year 1 (Ibá 2019). These two groups of species combined comprise $92 \%$ of the tree plantations in Brazil (72\% eucaly pts and $20 \%$ pines) of a total of 7.83 million hectares. The remaining $8 \%$ comprise other species such as black wattle (Acacia mearnsii), rubber tree (Hevea brasiliensis), parica (Schizolobium amazonicum), populus (Populus deltoides) and teak (Tectona grandis) (Ibá 2019).

Among this group, teak plantations area has been expanding in the Brazilian forestry sector, largely targeting the international market. Even though teak was introduced in Brazil in the 1970's, only recently the area of plantations has considerably increased, currently covering an area of about 93,957 hectares (Ibá 2019).

The teak plantations in Brazil are concentrated mostly in Midwest Brazil, in the state of Mato Grosso (Famato 2013). This is one of the largest states in Brazil with an area of around $903.357 \mathrm{~km}^{2}$, which covers three Brazilian biomes: the Amazon rainforest in the north and southeast; the Pantanal (Brazilian wetlands) in the south; and the Cerrado (Brazilian savannah) in the central and westerns portions. This state is economically very important to Brazil due to the extensive areas of livestock production and intensive agriculture, including the world leading soy production.

The silviculture of teak in Brazil is currently not as developed as compared to the eucalypts and the pines, which have been intensively improved in terms of both genetics and silvicultural methods, resulting in tremendous gains in productivity. The choice of unsuitable sites and genetic material, as well as the application of inappropriate silvicultural practices, are factors that still hinder improvements in productivity of teak plantations in some sites in Brazil and in Central America (Tonini et al. 2009).

According to Golfari (1975), studies related to soil, climatic and physiographic characteristics and their relation to the silvicultural characteristics of species, should be the first steps to be taken before the establishment of forest stands. Studies such as edapho-climatic zonings and provenance-progeny trials provide a foundation of knowledge about the local and regional suitability and the productive potential of species, provenance or genotypes. This information can then be used to inform silvicultural and management decision making.

Emerging scientific studies that investigate the productive potential of teak plantations based on soil, climatic and physiographic information in Brazil are timely. It is not rare that the choice of area for planting be merely empirical, resulting in under-yielding stands (Leite et al. 2006).

Decision support sy stems that incorporate the productive potential of the site are essential in choosing appropriate sites for the cultivation of forest species (Dias et al. 2005). Various techniques have been shown to be effective in studies involving many environmental variables and their relationships. Such techniques include the association of spatial analysis tools (spatial and geostatistics) with geographic information systems (GIS), remote sensing and artificial intelligence, such as artificial neural networks (ANN). These techniques can be used to explore the effects of variables (continuous or categorical) on forest productivity, being a very useful analytical tool (Ortiz et al. 2006). Although ANN have been widely explored in other scientific fields, the application of ANN in forest modeling is relatively new. Several studies involving the use of ANN in Brazil have shown its effectiveness for modeling the growth and yield of eucalyptus (Martins et al. 2015; Silva Binoti et al. 2015)

In this study we assessed the productive potential of teak across the state of Mato Grosso, midwest Brazil, by modeling the teak stands productivity as a function of climatic, edaphic and physiographic characteristics using artificial neural networks.

\section{Materials and Methods \\ Characterization of the study area}

We used data were obtained from teak plantations from different regions of the state of Mato Grosso, located in the Midwest region of Brazil $\left(06^{\circ} 00^{\prime} \mathrm{S}-19^{\circ} 45^{\prime} \mathrm{S}\right.$ and $50^{\circ} 06^{\prime} \mathrm{W}$ - $62^{\circ} 45^{\prime} \mathrm{W}$ ), which includes the geodesic center of South America. The state covers three Brazilian biomes: Cerrado, Pantanal and the Amazon; and three major river basins: Amazon Basin, Platina Basin and the Tocantins Basin. The main types of climate are: humid continental equatorial, with well-defined dry season in the South Amazon depression; humid continental subequatorial, with well-defined dry season in the Parecis plateau; and wet and dry continental 
tropical, in the other plateaus, plains and depressions. The rainfall varies from 1000 to $2000 \mathrm{~mm}$ per year. The relief is characterized by plateaus, depressions and plains with altitudes ranging from 100 to $1200 \mathrm{~m}$ (Mato Grosso State Government 2016).

\section{Variables}

The environmental variables that we related to productivity comprised of climatic, edaphic and physiographic variables. The climatic variables were: maximum, mean and minimum temperatures; wind speed; rainfall; potential and real evapotranspiration; relative air humidity; solar radiation; water deficit and water excess; and duration of the wet season. The edaphic variables were soil class, texture, effective depth and drainage. The physiographic variables were altitude, aspect, slope and the topographic wetness index (TWI). The summary statistics of the continuous variables and levels of the categorical variables are presented in Table 1 and Table 2 .

Table 1. Summary statistics of the climatic and phy siographic variables used in the training of artificial neural networks to assess the productive capacity of teak plantation across state of Mato Grosso, Midwest Brazil.

\begin{tabular}{|c|c|c|c|c|}
\hline Variable & Minimum & Maximum & Average & $\begin{array}{l}\text { Standard } \\
\text { deviation }\end{array}$ \\
\hline $\begin{array}{l}\text { Mean anual } \\
\text { temperature }\left({ }^{\circ} \mathrm{C}\right)\end{array}$ & 24.3 & 27.4 & 26.3 & 0.4 \\
\hline $\begin{array}{l}\text { Minimum anual } \\
\text { temperature }\left({ }^{\circ} \mathrm{C}\right)\end{array}$ & 17.9 & 22.3 & 20.3 & 0.6 \\
\hline $\begin{array}{l}\text { Maximum anual } \\
\text { temperature }\left({ }^{\circ} \mathrm{C}\right)\end{array}$ & 30.7 & 33.2 & 32.3 & 0.3 \\
\hline $\begin{array}{l}\text { Annual mean wind } \\
\text { speed }\left(\mathrm{m} \mathrm{s}^{-1}\right)\end{array}$ & 0.7 & 1.2 & 0.9 & 0.1 \\
\hline $\begin{array}{l}\text { Mean } \\
(\mathrm{mm})\end{array} \quad$ rainfall & 1202.5 & 2498.4 & 1767.5 & 253.9 \\
\hline $\begin{array}{l}\text { Annual mean } \\
\text { relative air } \\
\text { humidity }(\%)\end{array}$ & 69.0 & 83.5 & 75.9 & 3.3 \\
\hline $\begin{array}{l}\text { Annual mean } \\
\text { potential } \\
\text { evapotranspiration } \\
(\mathrm{mm})\end{array}$ & 1287.5 & 1505.0 & 1382.9 & 41.8 \\
\hline $\begin{array}{l}\text { Daily mean solar } \\
\text { radiation }\left(\mathrm{MJ} \mathrm{m}^{-2}\right)\end{array}$ & 16.0 & 18.6 & 17.5 & 0.5 \\
\hline $\begin{array}{l}\text { Annual mean real } \\
\text { evapotranspiration } \\
(\mathrm{mm})\end{array}$ & 1097.4 & 1331.0 & 1186.8 & 34.1 \\
\hline $\begin{array}{l}\text { Annual mean } \\
\text { water excess }(\mathrm{mm})\end{array}$ & 47.3 & 1282.8 & 581.3 & 262.1 \\
\hline $\begin{array}{l}\text { Annual mean } \\
\text { water deficit }(\mathrm{mm})\end{array}$ & 74.5 & 349.6 & 196.1 & 48.7 \\
\hline $\begin{array}{l}\text { Annual mean } \\
\text { duration of the dry } \\
\text { season (months) }\end{array}$ & 2.3 & 5.2 & 4.0 & 0.5 \\
\hline Altitude (m) & 64.0 & 1161.0 & 335.7 & 141.0 \\
\hline Slope $(\%)$ & 0.0 & 419.6 & 6.2 & 6.4 \\
\hline Aspect $\left({ }^{\circ}\right)$ & -1.0 & 359.9 & 174.7 & 105.4 \\
\hline $\begin{array}{l}\text { Topographic } \\
\text { wetness index }\end{array}$ & 2.1 & 29.4 & 8.4 & 2.6 \\
\hline
\end{tabular}

The climatic variables were obtained from Xavier et al. (2015). The authors developed a daily high-resolution grid of meteorological variables for Brazil, from 1980 to 2013, with a resolution of $0.25^{\circ} \times 0.25^{\circ}$ (about $28 \times 28 \mathrm{~km}$ ). The interpolated variables were the temperatures (maximum and minimum), solar radiation, relative humidity, wind speed, rainfall and potential evapotranspiration; which were obtained from 3625 rain gauges and 735 weather stations.
Table 2. Levels of the edaphic variables used in the training of artificial neural networks to asses the productive capacity of teak plantation across state of Mato Grosso, Midwest Brazil.

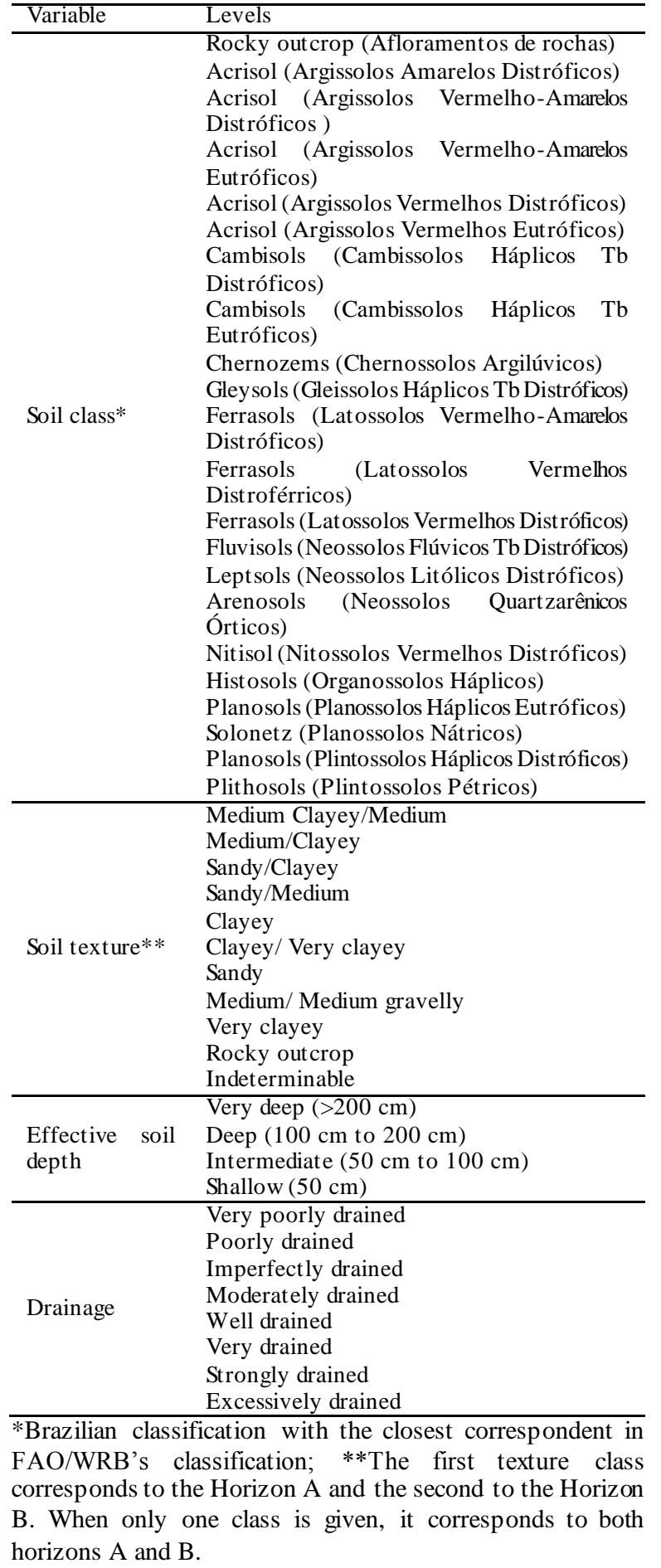

The mean temperature was obtained by averaging the maximum and minimum temperatures. The duration of the dry season was defined as the period with monthly rainfall equal to or less than $50 \mathrm{~mm}$ (Keogh 1987). The real evapotranspiration, water deficit and water excess were obtained by calculating the water balance, using the Thornthwaite and Mather method (1955). For this calculation the value for available water capacity of the soil (AWC) was set at $300 \mathrm{~mm}$, which is the recommended value for forested soils (Pereira et al. 2002). 
Data regarding soil class and texture was obtained from soil maps $(1: 250,000)$, which were originally used in the preparation of the Socio-Economic-Ecological Zoning of Mato Grosso (ZSEE-MT). These maps were made available by the Secretary of State for Planning of the state of Mato Grosso (Seplan 2001). The soil classes were updated to the third level of classification of the current Brazilian system of soil classification (SiBCS), according to Santos et al. (2011; 2013). The data for drainage and effective depth was obtained from the soil class characteristics described by Santos et al. (2013).

The variables altitude, aspect and slope were derived from the digital elevation model from the SRTM (Shuttle Radar Topography Mission) of the National Aeronautics and Space Administration of the United States of America (NASA), which mapped the earth's surface elevation by means of radar interferometry, producing digital elevation models (DEM) with spatial resolution of $30 \mathrm{~m}$ (obtained in http://earthexplorer.usgs.gov).

The topographic wetness index (TWI), which is used to quantify the effect of topography on hydrological processes (Qin et al. 2011; Sørensen et al. 2006), was calculated according to the methodology proposed by Moore et al. (1993) (equation 1):

$$
T W I=L n\left(\frac{S A}{\tan \beta}\right)
$$

where SA is the specific working area (accumulated flow), which is the area of contribution per unit of width, orthogonal to the direction of flow, multiplied by the grid size, in $\mathrm{m}^{2}$, and $\beta$ is the slope (degrees).

We used the mean annual increment at the age of 12 years $\left(\mathrm{MAI}_{12}\right)$ as a measure of productivity. This age is half of the expected rotation for teak in this region. We decided to include in the analysis, stands which did not reach this age, but which were close to it, i.e. stands which were 9 and 10 years old. By doing so, we considerably increased our dataset, allowing us to cover a larger area of the state. Therefore, it was necessary to project the net yield (including the volumes removed by thinning) of those stands to the age of 12 years. For that, equation 2 was fitted though ordinary mean squares using all available y ield data. Yield at 12 years was estimated with equation 3 , which uses the ration between the observed and estimated yield at a current age to adjust the estimated yield at 12 years (Campos and Leite 2017).

$$
\begin{aligned}
& \hat{Y}=\exp \\
& \hat{Y}_{12}=Y_{c} \exp ^{5.94012+\left(\frac{-8.28112}{A g e}\right)}\left(\mathrm{R}^{2}=0.55\right) \\
& \exp ^{-\left(5.94012-8.28112 \mathrm{Age}_{c}^{-1}\right)}
\end{aligned}
$$

where $\widehat{Y}$ is the yield at a given age; $\widehat{Y}_{12}$ is the estimated yield at 12 years; $Y_{c}$ is the observed yield at a current age $\left(A g e_{c}\right)$.

\section{Modeling}

We used artificial neural networks (ANN) to relate the $\mathrm{IMA}_{12}$ to the environmental variables mentioned in the previous section, in order to assess the patterns of the productivity of teak plantations across the state of Mato Grosso.

We used the software Neuroforest ${ }^{\circledR}$ (http://neuroforest.ucoz.com), version 4.0, for training and applying the ANN. The ANN's were of the type Multilayer Perceptron (MLP), with three layers: the inputs, the hidden layer and the outputs. The training algorithm used was the resilient propagation (Rprop +) (Heaton 2011).
The input layer had 39 neurons given the number of inputs, which derived from the climatic, edaphic and physiographic variables. The continuous variables were represented by only one neuron, whereas the categorical variables had one neuron for each level. The hidden lay er had 25 neurons and the output layer had a single neuron which corresponds to the response variable (IM A ${ }_{12}$ ). The activation function used for the hidden and output layers was of the sigmoid type. The stopping training criteria was met either when the average error reached 0.0001 or when the number of cycles reached 3000 .

The number of neurons in the hidden layer was chosen after a pilot analysis (not shown) when we tested several different sizes of hidden layer, training 10 ANN's for each size. All of the data was used for the training.

The best ANN was the one that resulted in a largest Pearson correlation coefficient between the observed and estimated values $\left(r_{y \hat{y}}\right)$ (equation 5 and equation 6 ), and the smallest root mean squared error (RMSE) (equation 7). Plots of the distribution of relative residuals (RR, equation. 8) were also used to aid the choice of the best ANN.

$$
\begin{aligned}
& r_{y \hat{y}}=\frac{n^{-1}\left(\sum_{i=1}^{n}\left(\hat{y}_{i}-\hat{y}_{m}\right)\left(y_{i}-\bar{y}\right)\right)}{\sqrt{\left(n^{-1} \sum_{i=1}^{n}\left(\hat{y}_{i}-\hat{y}_{m}\right)^{2}\right)\left(n^{-1} \sum_{i=1}^{n}\left(y_{i}-\bar{y}\right)^{2}\right)}} \\
& \hat{y}_{m}=n^{-1} \sum_{i=1}^{n} \hat{y}_{i}
\end{aligned}
$$

$$
\begin{aligned}
& R M S E=100 \bar{Y}^{-1} \sqrt{n^{-1} \sum_{i=1}^{n}\left(y_{i}-\hat{y}_{i}\right)^{2}} \\
& R R_{\%}=100\left(\frac{\hat{y}_{i}-y_{i}}{y_{i}}\right)
\end{aligned}
$$

where $y_{i}$ e $\hat{y}_{i}$ are, respectively, the observed and estimated values of $\mathrm{IM} \mathrm{A}_{12} ; i$ is the a ith observed values; $\bar{y}$ is the mean value of $y ; \hat{y}_{m}$ is the mean value of the estimates of $y ; n$ is the number of observations.

The software ArcGIS version 10.1, developed by Environmental Systems Research Institute (Esri 2012) was used for data processing and for map building. The productivity classes were established by adding or subtracting one standard deviation (sd) of the $\mathrm{MAI}_{12}$ such as:

- $\quad$ High productivity: $\mathrm{MAI}_{12}>\overline{M A I_{12}}+1 \mathrm{sd}$;

- Intermediate productivity: $\overline{M A I_{12}}+1 \mathrm{sd}>\mathrm{MAI}_{12}>$ $\overline{M A I_{12}}-1 \mathrm{sd}$;

- Low productivity: $\mathrm{MAI}_{12}<\overline{M A I_{12}}-1 \mathrm{sd}$

The average mean annual increment $\left(\overline{M A I_{12}}\right)$ refers to the average $\mathrm{MAI}_{12}$ after spatialization of the environmental variables, obtained in the conversion of the points features in raster.

The overall performance (OP) of the classification was assessed by means of confusion matrix (Rodrigues et al. 2014), which is related to the accuracy or the degree of agreement between observed and estimated values in the productivity classes. The Kappa index (KI) (Landis \& Koch 1977) was used to assess the accuracy or quality of the 
estimates between the observed and the values estimated by the ANN, in their productivity classes.

The OP was calculated through equation 9; and the KI, which ranges from 0 (poor quality) to 1 (excellent), was calculated through equation 10 and equation 11 .

$$
\begin{aligned}
& O P=\left(\frac{D}{T}\right) \\
& I K=\left(\frac{D-Q}{T-Q}\right) \\
& Q=\left(\frac{E O^{*} E C}{T}+\ldots+\frac{E O n * E C n}{T}\right)
\end{aligned}
$$

where $I K$ is the Kappa index; OP is the overall performance; $D$ is the sum of the values in the matrix's main diagonal; $Q$ is the ratio between the error of commission and the error of omission; $T$ is the total of samples or squares from the grid; $\mathrm{CE}$ is the commission error and $\mathrm{OE}$ is the omission error.

\section{Results}

The correlation coefficient between the estimates and the observed $\mathrm{MAI}_{12}\left(r_{y \hat{y}}\right)$ and the root mean squared error (RMSE) were, respectively, 0.88 and 2.8. The plot of the estimates against the observed values and the residual dispersion are shown in Figure 1.


Figure 1: Estimates for the mean annual increment at 12 years old $\left(\mathrm{IM} \mathrm{A}_{12}\right)$ against their respective observed values (a) and dispersion of the relative error (b) from the best ANN trained to estimate the $\mathrm{IMA}_{12}$ of Tectona grandis plantations in Midwest Brazil, based on environmental variables.

The global performance, i.e. the degree of agreement between the observed and the estimated values of the RNA, for the lowest, intermediate and highest productivity classes were, respectively, 93\%, 76\% and $80 \%$. The Kappa index of 0.63 indicates a good agreement between the classification based on the observed and estimated values. The estimated $\mathrm{MAI}_{12}$ ranged from $1.73 \mathrm{~m}^{3} \mathrm{ha}^{-1}$ y ear ${ }^{-1}$ to $31.21 \mathrm{~m}^{3}$ ha $^{-1}$ year 1 , with a mean of $19.5 \mathrm{~m}^{3} \mathrm{ha}^{-1}$ year $^{-1}$, and a coefficient of variation of $47.48 \%$. The high productivity areas, established as $\mathrm{MAI}_{12}>28.76 \mathrm{~m}^{3} \mathrm{ha}^{-1}$ year $^{-1}$, were concentrated in the south, west and northwest regions, covering $18 \%$ of the state's area. The low productivity class, with $\mathrm{MAI}_{12}<10.24$ $\mathrm{m}^{3} \mathrm{ha}^{-1}$ year $^{-1}$, covered $20 \%$ of the land and was located in the Midwest region of the state. The greatest proportion of the state's land, i.e. $68 \%$, was classified in the intermediate productivity class with $10.24 \mathrm{~m}^{3} \mathrm{ha}^{-1}$ year $^{-1}>\mathrm{MAI}_{12}>28.76$ $\mathrm{m}^{3} \mathrm{ha}^{-1}$ year $^{-1}$ (Figure 2).

\section{Discussion}

Estimating forest productivity and potential productive capacity using environmental variables constitutes a useful tool for silviculture and forest management (Jiang et al. 2014; Bueis et al. 2016). It can potentially aid the decision making process in forest planning, such as land acquisition, provenance or genotype selection and planning of silvicultural treatments (Scolforo et al. 2013).

The artificial neural network stands out as a promising tool for this type of modeling (Cosenza et al. 2017). In our work, the effectiveness of the ANN was supported by the high value of $r_{y \hat{y}}(0.88)$, the low value of RMSE (2.8\%) and the satisfactory dispersion in the error and observed values vs estimates graphs (Figure 1). In addition, the global performances and Kappa index indicated that the classifications were consistently reliable (Landis \& Koch 1977).

These results could have had even greater accuracy if more sample points distributed across the state were included in the ANN training. From the total state area grid, $0.12 \%$ was used in this work. This was the maximum on ground information which was made available and for which a reasonable number of environmental variables could be collected. Also, the soil depth was the only variable with data available for $100 \%$ of the state land.

There are some instances where inconsistencies between our classification or estimates, and real values of productivity not covered by our sampling area, are evident. One example of this is in the extreme over or underestimation of IMA 12 These inconsistencies may arise from a lack of variables that play an important role in restricting or favoring the growth of teak trees. For example, the southeastern region of Mato Grosso state was classified as having high productivity. Some areas in this region reach altitudes over $1000 \mathrm{~m}$, which has already been shown to restrict the growth of teak trees (Pandey \& Brow 2000; Midgley et al. 2015). The greatest altitude recorded in our data was only $400 \mathrm{~m}$ and thus the growth of teak trees in our sites would not be restricted by altitude. However, estimates for areas of the state which are actually higher than $1000 \mathrm{~m}$ would lack the altitude growth restriction.

Further, in the northwest region, high levels of productivity were expected. However, there was no observed data available and some important environmental variables were missing. Such variables include water excess and minimum temperature, which have also been shown to restrict the growth of teak trees (Pandey \& Brow 2000; Midgley et al. 2015). We were therefore unable to test whether observed IMA levels were comparable to expected levels in this area.

According to Braga et al. (2000), during the training, the ANN extracts the characteristics necessary to represent the information contained in the data and generate responses to a given problem. The consistency of the outputs for cases not given in the learning is related to the ANN's ability of generalization. Very unbalanced data used in the learning may result in biased estimation, i.e., towards values close to the more frequent values in the data (Silva et al. 2010). 


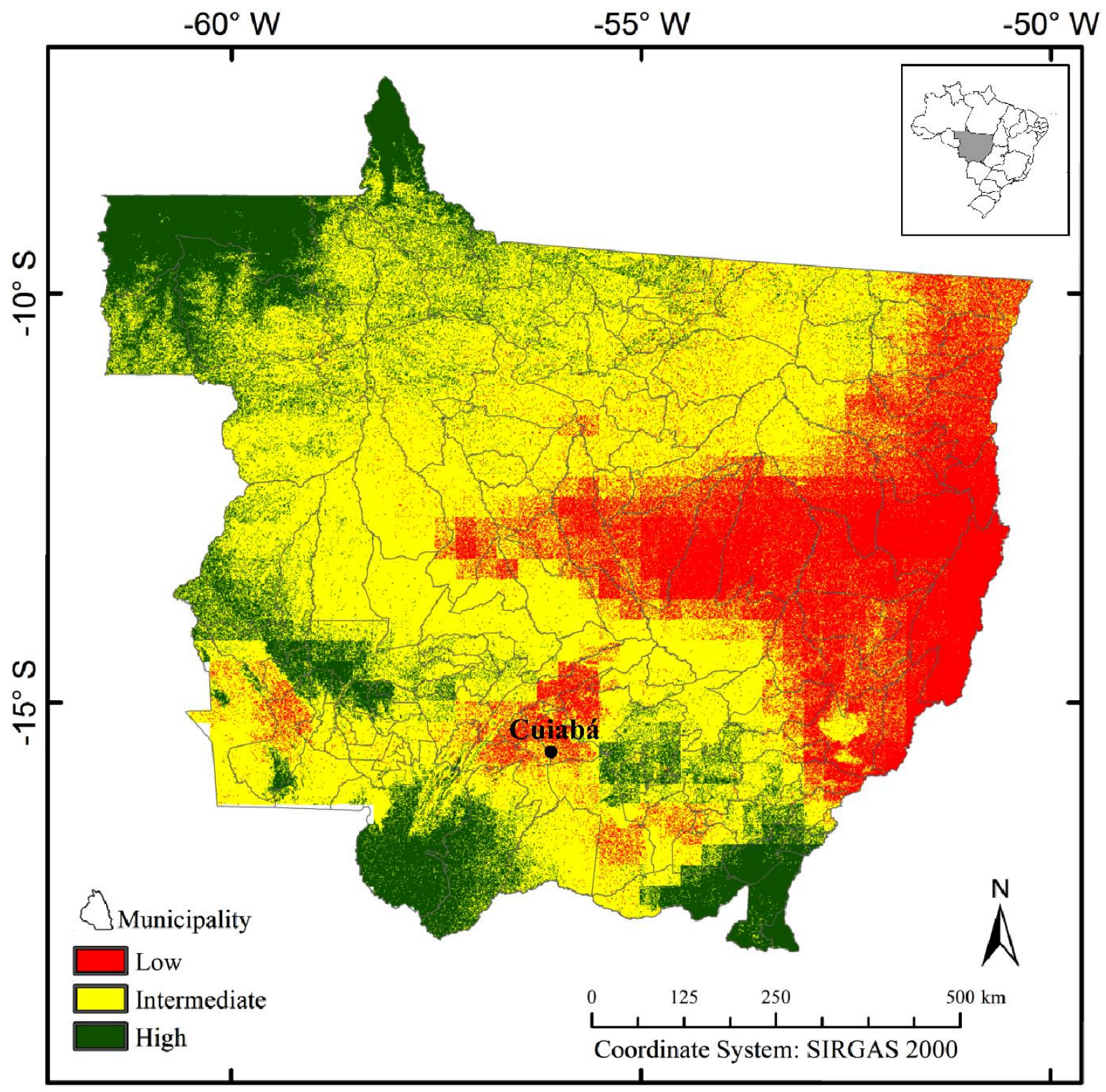

Figure 2. Productive potential estimated by artificial neural networks for Tectona grandis stands in Midwest Brazil, using climatic, edaphic and phy siograp hic variables. Despite these drawbacks, we highlight that our work is the first in Brazil to map the productive potential of teak plantations. As already mentioned, the silviculture of teak is still in the early stages of development in Brazil, lacking the initiative demonstrated in this paper. Here we show how ANN analy sis can be used to create land suitability maps, and reasonable yield expectations for use by government agencies, companies and foresters looking to competitively produce teak.

More comprehensive environmental data, as well as variables related to silvicultural aspects such genotypes, initial spacing, weed control, fertilization, thinning intensity and others, is becoming ever more available as teak plantations expands throughout the state of Mato Grosso and other regions of Brazil. Using this data will allow for the creation of more precise and robust productive capacity mappings, contributing to the development of teak silviculture in Brazil and potentially in regions with similar environmental characteristics.

\section{Conclusion}

RNA were efficient to express the productive potential only for areas where there is observed productivity data.

To assess the productive potential with RNA, a representative database of environmental conditions is needed for more accurate estimates in the training and generalization. More specific studies are necessary involving management regimes, individual effect of environmental variables and also interactions between them over the productivity of teak in a complete rotation.

\section{Acknowledgments}

We thank the Foundation for Research and Extension Support of the state of Mato Grosso (FAPEMAT) for granting the scholarship to the first author and the Brazilian National Council of Technological and Scientific Development (CNPq) for the research productivity grant to the second and seventh authors. The Foresters Association of Mato Grosso (AREFLORESTA).

\section{References}

Binoti MLM S, Leite HG, Binoti DHB, Gleriani JM. Prognose em nível de povoamento de clones de eucalipto empregando Redes Neurais Artificiais. Cerne 2015; 21(1): 97-105. doi: 10.1590/01047760201521011153 
Braga AP, Carvalho APLF, Ludemir TB. Redes neurais artificiais: teoria e aplicações. Rio de Janeiro: Editora LTC, 2000 .

Bueis T, Bravo F, Pando V, Turrión MB. Relationship between environmental parameters and Pinus sylvestris $\mathrm{L}$. site index in forest plantations in northern Spain acidic plateau. iForest-Biogeosciences and Forestry 2016; 9: 394401. doi: 10.3832/ifor1600-008

Campos JCC, Leite HG. Mensuração florestal: perguntas e respostas. 5. ed. Viçosa: UFV, 2017.

Cosenza DN, Soares AAV, Alcântara AEM, Silva AAL, Rode R, Soares VP, et al. Site classification for eucalypt stands using artificial neural network based on environmental and management features. Cerne 2017: 23(3): 310-320. doi: 10.1590/01047760201723032352

Dias AN, Leite HG, Campos JCC, Couto L, Carvalho AF. Emprego de um modelo de crescimento e produção em povoamentos desbastados de eucalipto. Revista Árvore 2005; 29(5): 731-739. doi: 10.1590/S010067622005000500008

Esri - Environmental Systems Research Institute. ArcGIS. Professional GIS for the desktop, version 10.1. 2012.

Famato. Diagnóstico de florestas plantadas do estado de Mato Grosso. Cuiabá: Instituto Mato-Grossense de Economia Agropecuária (Imea), 2013.

Golfari L. Zoneamento ecológico do estado de Minas Gerais para reflorestamento. Belo Horizonte: PNUD/FAO/IBDF/PRODEPEF, 1975.

Gonçalves JLM, Stape JL, Laclau J-P, Smethurst P, Gava JL. Silvicultural effects on the productivity and wood quality of eucalypt plantations. Forest Ecology and Management 2004; 193: 45-61. doi: 10.1016/j.foreco.2004.01.022

Heaton, J. Programming neural networks with encog3 in java. 2nd Edition. St. Louis: Heaton Research, Inc., 2011.

Ibá. Annual Report of the Brazilian Trees Industry. São Paulo. 2019.

Jiang H, Radtke PJ, Weiskittel AR, Coulston JW, Guertin PJ. Climate-and soil-based models of site productivity in eastern US tree species. Canadian Journal of Forest Research 2014; 45: 325-342. doi: 10.1139/cjfr-2014-0054

Keogh RM. The care and management of teak (Tectona grandis L.f.) plantations. Heredia, Costa Rica: Universidad Nacional, 1987.

Landis JR, Koch GG. The measurement of observer agreement for categorical data. Biometrics 1977; 33(1): $159-174$.

Leite HG, Nogueira GS, Campos JCC, Takizawa FH, Rodrigues FL. Um modelo de distribuição diamétrica para povoamentos de Tectona grandis submetidos a desbaste. Revista Árvore 2006; 30(1): 89-98. doi: 10.1590/S010067622006000100011

Martins ER, Silva Binoti MLM, Leite HG, Binoti DHB, Dutra GC. Configuração de redes neurais artificiais para prognose da produção de povoamentos clonais de eucalipto. Revista
Brasileira de Ciências Agrárias 2015; 10(4): 532-537. doi: 10.5039/agraria.v10i4a5350

Mato Grosso State Government. Mato Grosso: geografia. Disponível em: <http://www.mt.gov.br/geografia>. Acesso em 10 de Ago. de 2016.Midgley S, Somaiy a RT, Stevens PR, Brown A, Kien ND, Laity R. Planted teak: global production and markets, with reference to Solomon Islands. Canberra: Australian Centre for International Agricultural Research (ACIAR), 2015.

Moore ID, Gessler PE, Nielsen GA, Peterson GA. Soil attribute prediction using terrain analysis. Soil Science Society of America Journal 1993; 57(2): 443-452. doi: 10.2136/sssaj1993.03615995005700020026x

Ortiz JL, Vettorazzi CA, Couto HTZ, Gonçalves JLM. Relações espaciais entre o potencial produtivo de um povoamento de eucalipto e atributos do solo e do relevo. Scientia Forestalis 2006; 72: 67-79.

Pandey D, Brown C. Teak: A global overview. Unasylva 2000; 51 (201): 3-13.

Pereira AR, Angelocci LR, Sentelhas PC. Agrometeorologia - fundamentos e ap licações práticas. Guaíba: Agropecuária, 2002.

Qin CCZ, Zhu AX, Pei T, Li BL, ScholtenT, Behrens T, Zhou C. An approach to computing topographic wetness index based on maximum downslope gradient. Precision Agriculture 2011, 12(1), 32-43. doi:10.1007/s11119-0099152-y

Rodrigues MT, Rodrigues BT, Tagliarini FSN. Comparação do desempenho de sistemas de informação geográfica (IDRISI Selva e ArcGIS®) por meio de processamento digital de imagem. X Fórum Ambiental da Alta Paulista 2014; 10(2): 265-280.

Santos HG, Carvalho Júnior W, Dart RO, Áglio MLD, Sousa JS, Pares JG, et al. O novo mapa de solos do Brasil: legenda atualizada. Rio de Janeiro: Embrapa Solos, 2011.

Santos HG, Jacomine PKT, Anjos LHC, Oliveira VÁ, Lumbreras JF, Coelho MR, et al. Sistema brasileiro de classificação de solos. 3 ed. Rio de Janeiro: Embrapa Solos, 2013.

Scolforo JRS, Maestri R, Ferraz Filho AC, Mello JM, Oliveira AD, Assis AL. Dominant height model for site classification of Eucalyptus grandis incorporating climatic variables. International Journal of Forestry Research 2013; 2013: 1-7. doi: 10.1155/2013/139236

Seplan. Mapa de solos do estado de Mato Grosso. 2001. Disponível em: <http://feicoes.seplan.mt.gov.br/>. Acesso em: 28 mar. 2016.

Silva IN, Spatti HD, Flauzino RA. Redes neurais artificiais: para engenharia e ciências aplicadas. Artliber: Artliber, 2010.

Sørensen R, Zinko U, Seibert J. On the calculation of the topographic wetness index: evaluation of different methods based on field observations. Hydrology and Earth System Sciences 2006, 10(1), 101-112. doi: 10.5194/hess-10-1012006 
Thornthwaite CW, Mather JR. The water balance: publications in climatology. New Jersey: Drexel Institute of Technology, 1955.

Tonini H, Costa MCG, Schwengber LAM. Crescimento da teca (Tectona grandis) em reflorestamento na Amazônia Setentrional. Pesquisa Florestal Brasileira 2009; 59: 5-14. doi: $10.4336 / 2009 . p f b .59 .05$

Xavier AC, King CW, Scanlon BR. Daily gridded meteorological variables in Brazil (1980-2013). International Journal of Climatology 2015; 36(6): 2644 2659. doi: 10.1002/joc. 4518 . 